\title{
THE MECHANISM OF HEPATIC COMA
}

\author{
By A. G. RIDDELL, M.B.E., M.S., F.R.C.S. \\ Lecturer in Surgery, University of Manchester
}

The coma, which occurs in severe liver disease, has been known since the time of Hippocrates, but its aetiology is unknown and has been a subject for speculation. In 1952, two groups of investigators in Boston made observations which gave a new approach to the problem (Gabudza, Phillips and Davidson, 1952 ; Phillips, Schwartz, Gabudza and Davidson, 1952; McDermott and Adams, 1954). This stimulus had led a number of workers to investigate hepatic coma. It is the purpose of the writer to describe the current views on the mechanism of hepatic coma and to discuss the role of ammonia as an aetiological factor in this condition.

\section{Clinico-Pathological Findings}

It should be made clear at the outset, that among a group of patients with severe liver disease a number of neurological disturbances will be met with; not all of these are the disease known as hepatic coma. Among these other states are the psychoses associated with chronic alcoholism and nicotinic acid deficiency, electrolyte disturbances, septicaemia, increased response to narcotics and subdural haematoma. Hepatic coma has a characteristic symptom complex and is associated with changes in the electroencephalogram, which are typical of the disease (Foley, Watson and Adams, 1950). For recent reviews of the clinical features of hepatic coma the reader is referred to the papers of Walshe (195 I) and Adams and Foley (1953).

In patients dying from the disease or in patients who have survived to die later from some other cause, a characteristic histological change has been found in the brain (Adams and Foley, 1953). This is a diffuse proliferation and hyperplasia of the nuclei of the protoplasmic astrocytes, which is found in the cerebral cortex, basal ganglia, red nucleus, pontine nuclei, dentate nuclei and Purkinje layer of the cerebellum but not in the hypothalmic nuclei, somatic nuclei of the brain stem nor the spinal cord. The significance of this change is not immediately clear, and it is unlikely that a diffuse glial change of this type would cause the neurological symptoms. It is more likely that the histological appearance is a reflection of acw diffuse neuronal disturbance affecting the brain. Apart from the direct interest of these findings, that they are the first definite account of a neuro logical change in hepatic coma, they are also of interest in that they form a method of assessing certain experimental work in animals (Riddell, $\infty$ 1954).

The Precipitating Factors in Hepatic Coma

Although Burchi (1927) may be credited with the first recorded instance of suspected ammoniof intoxication in man with cirrhosis of the liver, the first major work on this subject is that of $\mathrm{Van}^{3}$ Caulaert, who published a series of papers on the significance of discorded ammonia metabolism yn liver disease (Van Caulaert and Deviller, 1959 Van Caulaert, Deviller and Halff, 1932a, 19325) Under the title of 'Transient Hepatargy, Gaustad (I949) discussed the mechanism of comæy in four patients with cirrhosis, all of whom re $\frac{\Omega}{\Omega}$ covered. He noted that in each instance the onset was precipitated by a severe haemorrhage from? oesophageal varices. Four other patients, with as severe degree of cirrhosis, were given urea by mouth and this resulted in the development of mental changes. Coma of short duration occurrefs in another patient who consumed $25^{\circ} \mathrm{g}$. of dried milk powder in one day. Gaustad concluded that $\mathrm{B}$. the cause of the symptoms in these cases was and unidentified nitrogenous substance formed from urea by bacterial action in the bowel.

A syndrome indistinguishable from hepatic coma following the administration of an ammonium on containing cation exchange resin to patients with cirrhosis of the liver, has also been reportedos (Gabudza, Phillips and Davidson, 1952). Later N Phillips, Schwartz, Gabudza and Davidson (1952) స్త reported their findings on a group of nine chronic alcoholics, with advanced cirrhosis, who were given various nitrogenous substances. Five oral medica- 0 tions were employed: ammonium chloride, diammonium citrate, ammonium-potassium ex=change resin, urea, and a high protein diet5 consisting of $15 \circ \mathrm{g}$. of protein a day. A reaction 
resembling the onset of hepatic coma occurred in five of the nine patients. The mental disturbances varied from a mild impairment of consciousness to gross confusion, and although one patient exhibited a peculiar state of disturbed consciousness with automatism, none became comatose. The mental changes were accompanied by the flapping tremor of the outstretched hand, described by Adams and Foley (1949) as characteristic of impending hepatic coma, and also by electroencephalographic changes typical of the same condition. This reaction occurred in two patients who were given the ammonium-containing resin and they experienced similar difficulties when given ammonium chloride. A third patient developed symptoms with one course of diammonium citrate and three courses of urea respectively, but not with a high dietary intake of protein. In two other patients the syndrome was produced with a high protein diet. Attempts to produce any untoward effects in four patients who were given ammonium chloride (one), diammonium citrate (one), urea (two) or increased dietary protein (three), failed. Studies of the blood ammonia concentration were made in this trial but the correlation between the blood level and the abnormal signs observed was not consistent enough to establish a relationship.

McDermott and Adams (1954) reported on a patient who had repeated episodes of confusion and coma after an operation for carcinoma of the pancreas, in which continuity of the portal circulation was restored by a portacaval anastomosis. Again, in this man the neurological disorder was produced by a high protein diet, urea, ammonium chloride and an ammonium-containing cation exchange resin. The patient had normal liver function tests and it is therefore highly significant that the syndrome of so-called hepatic coma could occur in a patient without liver disease.

Another substance which may precipitate hepatic coma in patients with cirrhosis is methionine (Singh, Barclay and Cooke, 1954; Sherlock, Summerskill, White and Phear, 1954). The mechanism by which methionine acts is uncertain; studies on the Eck fistula dog show that methionine intoxication is not associated with any significant rise in blood ammonia level (Riddell, unpublished).

\section{The Biochemical Changes in Hepatic Coma}

The reports of the precipitation of hepatic coma by compounds which might liberate ammonia, described above, have led a number of workers to measure the ammonia concentration in the peripheral blood in patients with hepatic coma (Phillips, Schwartz, Gabudza and Davidson, 1952; Traeger, Gabudza, Ballou and Davidson, 1954;
Singh, Barclay and Cooke, 1954; Riddell and McDermott, 1954; Seegmiller, Schwartz ando Davidson, 1954; McDermott, Adams and Riddell $\stackrel{\complement}{\varrho}$ 1954; Sherlock, Summerskill, White and Phear, 1954).

All workers are agreed that in severe liver diseaseo with impending hepatic coma, the blood ammoniao level is elevated in the peripheral blood but there is no agreement as to the significance of this finding. $\frac{\mathbb{}}{2}$ Part of this difficulty has arisen from each labora- 0 tory using a different modification of the Conway, microdiffusion technique for the estimation of the $\overrightarrow{ }$ blood ammonia (Conway, 1950).

Using the method reported by McDermott and Adams (1954), McDermott, Adams and Riddell: (1954) considered the following values to be re-3. presentative for a fasting human subject: Peripheral venous blood, $50 \mu \mathrm{g}$.; ${ }^{*}$ portal vein, $250 \mu \mathrm{g}$. $\overrightarrow{\dot{\omega} \omega}$ hepatic vein, $80 \mu \mathrm{g}$.; renal vein, 100 $\mu \mathrm{g}$.

The figure given for portal vein blood is representative of the fasting state, observed at 0 operation. After a protein meal the ammonia con-윽 centration in the portal vein will rise to high levels.In the cat, after a protein meal, a level of $1,000 \gg$ $\mu \mathrm{g}$. per cent. has been reported (Folin and Denis, 1912). The renal vein ammonia level was foundos to be consistently higher than that in the renal $\vec{c}$ artery, therefore the kidney does not clear ammonacy from the peripheral blood but rather contributes. to it. The ammonia in the portal vein is derived from the action of micro-organisms within the lumen of the gut by their action on amino acids ando urea (Dinsis and Hastings, 1954).

In 29 patients with hepatic coma studied at the $\stackrel{\mathbb{D}}{2}$ Massachusetts General Hospital, a correlation be- $\overrightarrow{0}$ tween blood ammonia concentration and the 3 neurological state was obtained. Neurological symptoms were present when the blood ammonia? level was more than $200 \mu \mathrm{g}$. per cent., and out of $\overline{0}$ I6 patients who had blood ammonia levels of 300. $\mu \mathrm{g}$. or above all except one were in coma (Riddello and McDermott, 1954). In patients who have? undergone shunt surgery for portal hypertensiono the correlation between blood ammonia level and $₹$ neurological status has been more marked? (McDermott, Adams and Riddell, 1954).

The views of Davidson on this problem may․ㅡㄹ. perhaps be best expressed by a quotation from onen of his recent papers: "The available data in-o criminate some defect in the metabolism of nitro- $N$ gen in the pathogenesis of hepatic coma. Blood N "ammonia" levels, however, failed to correlateo consistently with the mental status of patients witho liver disease. This may mean that the method for measuring blood "ammonia" may not be?

* Micrograms of ammonia-nitrogen per $100 \mathrm{ml}$. of $\frac{\vec{\Phi}}{\vec{D}}$ whole blood. 
sufficiently specific so that, in addition to ammonia, it may be detecting to a varying degree other substances which may be toxic. Other interpretations are also possible. It may be that the extracellular ammonia concentration measured does not indicate the quantity of intracellular ammonia, which may be closely related to ammonia toxicity. Finally, the neurological changes may be related to some derivative of ammonia, for example, glutamine, which is known to be present in high concentrations in the brains of hepatectomized dogs, and has been found by Walshe in urine of patients with hepatic coma. Although of all the measurements so far made in patients with liver coma the blood " ammonia " correlated best with the clinical status, further investigation is necessary to elucidate these possible relationships between ammonia metabolism and liver coma' (Traeger, Gabudza, Ballou and Davidson, 1954).

Singh, Barclay and Cooke (1954) found no direct correlation between the blood ammonia level and the clinical state and concluded that "the blood ammonia is more an indicator of the extent of the collateral circulation than of cellular dysfunction.'

In the patient with an Eck fistula (McDermott and Adams, 1954) it was found that a high blood ammonia preceded the onset of the neurological symptoms and these would persist for 24 to 48 hours after the blood ammonia level had fallen to relatively low levels. In this patient the degree of correlation between blood ammonia level and neurological status was convincing.

In an attempt to clarify the situation experiments have been performed on dogs with portacaval anastomoses (Eck fistulae) (Riddell, Kopple and McDermott, I954). It had been known for many years that when Eck fistula dogs were fed meat neurological symptoms developed, the aetiology of which were obscure. Previous workers have reported high blood ammonia levels in meat intoxication (Hahn, Massen, Nencki and Pavlov, 1893; Monguió and Krause, 1934). In the present series of experiments it was found that just as in the patient of McDermott and Adams, a high blood ammonia level preceded the onset of the symptoms and these persisted for some time after the blood ammonia level had fallen. Further, it was found that symptoms could be produced by injecting small doses of urease intravenously to raise the blood ammonia level to that concentration which had been previously observed in a dog with mild symptoms of meat intoxication; again symptoms occurred. These experiments appeared to the authors to demonstrate that the neurological symptoms were directly related to the presence of ammonia in the peripheral blood. However, these experiments do not indicate whether the ammonia is free in the blood or in loose chemical combina- $\frac{0}{3}$ tion. Certain observations on the blood and $\stackrel{\mathbb{Q}}{\complement}$ cerebrospinal fluid in patients with hepatic coma $c$ suggest that ammonia may exist in the free state in $\vec{F}$ the blood (McDermott, Adams and Riddell, 1955). $\stackrel{\text { ? }}{9}$ It is of interest that the dogs which died of meat? intoxication showed the same histological changes $\frac{\overline{ }}{\bar{N}}$ as patients dying of hepatic coma (Riddell, 1954).

The other notable biochemical changes in $\mathbb{2}$ hepatic coma concern glutamine and some components of the citric acid cycle. An increase in the $\vec{A}$

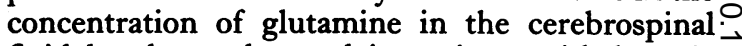
fluid has been observed in patients with hepatic $\vec{\omega}$ coma (Walshe, I95I). It has also been found that $\stackrel{\odot}{\circ}$ after total hepatectomy in dogs the concentrationo of glutamine in the brain rises and the glutamic 3 . acid concentration falls. (Flock, Block, Grindlay, Mann and Bollman, 1953).

Studies by several groups of workers have demonstrated that carbohydrate metabolism is $\dot{\omega}_{\infty}$ disturbed. The blood pyruvate has been found to $\subseteq$ be raised (Snell and Butt, I94I; Amatuzio and $\mathrm{O}$ Nesbitt, 1950; Bueding, Wortis, Stern and Eusteronne, 1942) and Seligson, McCormick and Sborov (1952) found elevation of blood pyruvate and alpha-ketoglutarate in patients with liver $\stackrel{\rho}{?}$ injury. These-findings have been confirmed $\overrightarrow{0}$ Carfagno, De Horatius, Thompson and Schwag G (1953), who studied I I cases of hepatic comâ:Their results may be summarized as follow

Pyruvic acid (nine cases), range $2.5^{2}$ to $19.5 \mathrm{mg}$. per cent. (normal r.o mg. per cent.).

Lactic acid (nine cases), range 15.1 to $65.2 \mathrm{mg}$. per cent. (normal ro.o mg. per cent.).

Alpha-ketoglutaric acid (one case), I.I $3 \mathrm{mg}$. perô를 cent. (normat $0.6 \mathrm{mg}$. per cent.).

\section{Interpretation of the Biochemical Findings in Hepatic Coma}

From the foregoing account of the biochemical changes in hepatic coma it would appear that this 3 . disorder is in some way related to a disturbance of ammonia metabolism. Whether free ammonia 3 occurs in toxic amounts in the peripheral blood of patients with hepatic coma remains unproved, The author believes that it is likely that it does. and the poor correlation between blood ammonia level and the neurological state that occurs in some ${ }_{\mathscr{O}}^{N}$ patients with hepatic coma is best explained on the basis that the change in the peripheral blood does not reflect accurately the intracellular concentration $\omega$ of ammonia.

If is probable that ammonia is toxic to brain cells by inhibiting the aerobic metabolism of glucose by interfering with the citric acid cycle; alpha-ketoglutaric acid is removed from the cycle to synthesize glutamic acid, which combines with ammonia to form glutamine (see Fig. r). 


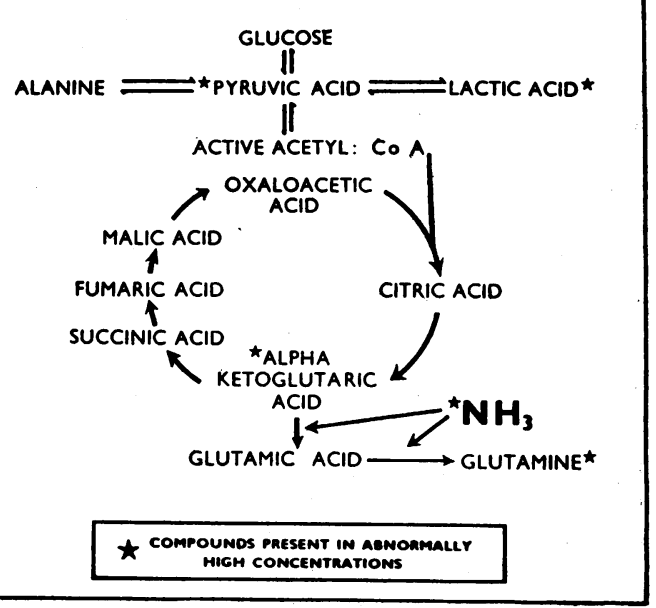

FIG. 1.-The biochemical abnormalities in hepatic coma. A schematic representation of a possible inter-relationship between ammonia and carbohydrate metabolism.

\section{The Practical Application of the Concept of Ammonia Intoxication}

The development of the conceptual scheme that ammonia intoxication plays an important role in the production of hepatic coma would be of little value at the present time if it were not for its practical application. An outline of the treatment of ammonia intoxication is given in Table $I$ and largely follows on the foregoing discussion, but there are several further points that need emphasis.

TABLE I

Treatment of Ammonia Intoxication

\section{Precipitating Factors:}

I. High protein diet, urea, ammonium chloride and ammonium containing resins.

2. Blood in the alimentary tract (from oesophageal varices).

\section{Active Treatment:}

I. Arrest haemorrhage by oesophageal tamponage.

2. Support carbohydrate metabolism.

3. Depress activity of bacterial flora in alimentary tract.

4. Glutamic acid therapy.

These are the value of blood ammonia determinations in the treatment of individual patients, the management of bleeding oesophageal varices and glutamic acid therapy.

A single blood ammonia determination in a patient with neurological symptoms and liver disease does not usually materially assist in the diagnosis or treatment of the patient. However, daily readings over a period of time may be of considerable value in the diagnosis of obscure cases. Two patterns of abnormal blood ammonia concentration occur in hepatic coma (Riddell and McDermott, 1954). These are represented dia $\mathbb{8}$ grammatically in Fig. 2; Type I, the steadily rising. curve, is the pattern found in terminal hepatiz. failure and has not been observed in other types of cases unless a high protein diet is persisted wit in the presence of severe liver damage. Type IF the rapid rise and then the fall, is found in patients with bleeding oesophageal varices. This type o\& curve is similar to that seen in man or animals with an Eck fistula. In such cases the neurological signo do not improve immediately the blood ammonia level falls but remain constant for several days before the patient begins to improve. It is this type of patient in whom treatment should be persisted with.

It has been thought that the coma that follows haemorrhage from oesophageal varices was due to the anoxic necrosis which occurred in the liver aso a result of oligaemia. That this is not the primar $\$$ cause of the coma can be demonstrated by feeding blood to an Eck fistula dog by means of a stomact tube (Riddell, I955). In such an experiment following the ingestion of the blood, there is rapid increase in blood ammonia level and this soon followed by the appearance of neurologicat signs. The immediate application of these $8 \times \overrightarrow{x e}$ periments to clinical practice is clear. It is equigly important in the treatment of bleeding oesophage varices to prevent blood entering the intestimat tract as it is to replace the blood loss. To achieve control of the bleeding varices, balloon tamponage as described by Saengstaken and Blakemore (195 aी should be resorted to.

Glutamic acid therapy in hepatic coma was first described by Walshe (1953), since which time there has been a tendency to use it indiscriminately An intravenous infusion of sodium glutamate will temporarily lower the blood ammonia leve् (Riddell and McDermott, I954), but when the infusion is discontinued the ammonia will return to its original level. Little can therefore be expected from glutamic acid therapy in a patient with of Type I blood ammonia pattern unless a causa् factor can be removed. On the other hand should be given early to patients with a Type curve in an attempt to hold down the temporar. rise of blood ammonia. Glutamic acid is also of value in the treatment of patients who have under gone the operation of portacaval anastomosis an have developed intolerance to protein (Riddelf 1955). It is estimated that in any large series of patients with portacaval or splenorenal shunts per cent. will demonstrate this condition.

\section{Summary and Conclusion}

The recent biochemical investigations on the mechanism of hepatic coma have been reviewea 
TYPE i
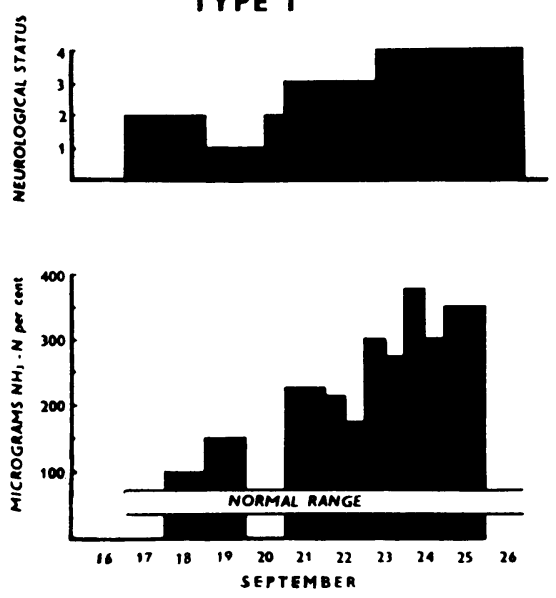

TYPE II
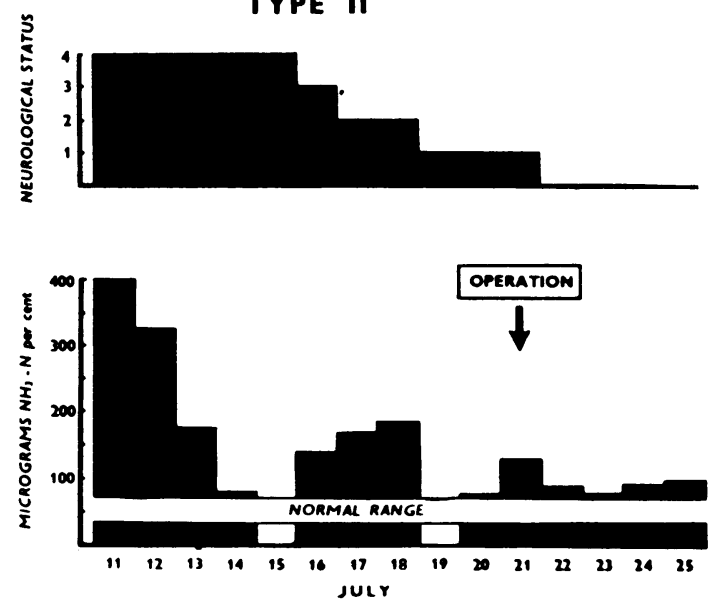

FIG. 2.-Blood ammonia determinations in hepatic coma. Type I the pattern of blood ammonia levels in coma due to hepatic failure; Type II the pattern following coma due to bleeding oesophageal varices. (Neurological status : $0=$ normal, $4=$ coma.)

and it has been shown that the metabolism of ammonia is deranged.

The evidence for the existence of ammonia intoxication in hepatic coma has been discussed. It is believed that the provisional adoption of the concept of ammonia intoxication is a useful one in that it allows a rational form of therapy to be applied.

\section{Acknowledgments}

The author wishes to thank the Department of Medical Illustration of the Manchester Royal Infirmary for the preparation of the diagrams.

\section{BIBLIOGRAPHY}

ADAMS, R. D., and FOLEY, J. M. (1949), Trans. Amer. Neurol. Ass., 74, 217.

ADAMS, R. D., and FOLEY, J. M. (1953), Ass. Res. Nerr. Ment. Dis. Proc., 32, 198.

AMATUZIO, D. S., and NESBITT, S. (1950), 7. Clin. Invest., 29, 1486.

BUEDING, E., WORTIS, H., STERN, M., and EUSTERONNE, D. (1942), Ibid., 21,85 .

BURCHI, R. (1927), Kongress. Zentralbl. f. inn. med., 47, 80.

CARFAGNO, S. C., HORATIUS, DE R. F., THOMPSON, C. M., and SCHWARZ, H. P. (1953), New Engl. F. Med., 249, 303 .

CONWAY, E. J. (1950), 'Microdiffusion Analysis and Volumetric Error,' Crosby Lockwood and Son, Ltd., London.

DiNSIS, R. Z., and HASTINGS, A. B. (I953), Proc. Nat. Acad. $S c$, 39, $57 \mathrm{I}$.

FLOCK, E. V., BLOCK, M. A., GRINDLAY, J. H., MANN, F. C., BOLLMAN, J. L. (1953), F. Biol. Chem., 200, 529 .

FOLEY, J. M., WATSON, C. W., and ADAMS, R. D. (1950), Trans. Amer. Neurol. Ass., 75, I6I.

FOLIN, O., and DENIS, W. (r912), f. Biol. Chem., 11, i6r.
GABUDZA, G. J., PHILliPS, G. B., and DAVIDSON, C. S. (1952), New Engl. F. Med., 246, 124.

GAUSTAD, V. (1949), Acta med. Scand., 135, 354.

HAHN, M., MASSEN, O., NENCKI, M., and PAVLOV, J. (1893), Arch. f. exper. Path. u. Pharmakol., 32, 161.

MCDERMOT'T, W. V., JR., and ADAMS, R. D. (I954), f. Clin.

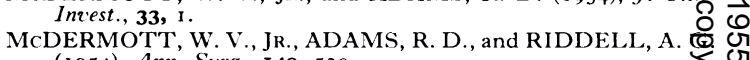
(1954), Ann. Surg., 140, 539.

MCDERMOT'T, W. V., JR., ADAMS, R. D., and RIDDELL, A. (1 955), Proc. Soc. Exper. Biol. and Med., 88, 380.

MONGUIO, J., and KRAUSE, F. (1934), Klin. Wchnschr., 13, 1142 PHILLIPS, G. B., SCHWARTZ, R., GABLDZA, G. I., and DAVIDSON, C. S. (1952), New Engl. F. Med., 247, 239 .

RIDDELL, A. G. (I954) 'Ammonia Metabolism and its Application in Surgery,' Thesis, University of London.

RIDDELL, A. G. (1955), Ann. Roy. Coll. Surg. Engl. (in press).

RIDDELL, A. G., KOPPLE, P. N., and MCDERMO'T', W. V., $\overline{\bar{O}}$ JR. (1954), Surgery, 36, 675 .

RIDDELL, A. G., and MCDERMOT'T, W. V., JR. (I 954), Lancet, i, 1263.

SAENGSTAKEN, R. W., and BLAKEMORE, A. H. (1950), Ann. Surg., 131, 781.

SEEGMILLER, J. E., SCHWARTZ, R., and DAVIDSON, C. S. (1954), F. Clin. Invest., 33, 984.

SELIGSON, D., MCCORMICK, G. J., and SBOROV, V. (1952), F. Clin. Invest., $31,66 \mathrm{I}$.

SHERLOCK, S., SUMMERSKILL, W. H. J., WHITE, L. P., and PHEAR, E. A. (1954), Lancet, ii, 453.

SINGH, I. D., BARCLAY, J. A., and COOKE, W. T. (1954) Ibid., i, 1004.

SNell, A. N., and BU'TT, H. R. (194I), Trans. Ass. Amer. Physicians, 56, 321 .

TRAEGER, H. S., GABUDZA, G. J., JR., BALLOU, A. N., and DAVIDSON, C. S. (1954), Metabolism, 3, 99.

VAN CAULAERT, C., DEVILleR, C. (1932), Compt. rend. Soc. I de Biol., III, 50.

VAN CAULAERT, C., DEVILLER, C., and HALFF, M. (1932a), N Ibid., III, 735.

VAN CAULAERT, C., DEVILLER, C., and HALFF, M. (1932b), N Ibid., III, 739 .

WALSHE, J. M. (195I), Quart. F. Med., 20, $42 \mathrm{I}$.

WALSHE, J. M. (1953), Lancet, i, 1075. 